\title{
PENGARUH INKUIRI TERBIMBING MELALUI MEDIA ADOBE FLASH TERHADAP HASIL BELAJAR KIMIA
}

\author{
Anggia Setianing Tyas $^{1^{*}}$ dan Lazulva \\ 1 Program Studi Pendidikan Kimia, Fakultas Tarbiyah dan Keguruan, \\ Universtas Islam Negeri Sultan Syarif Kasim Riau, Kampus II Raja Ali Haji. Jl. H. R. \\ Soebrantas KM. 15 Tampan, Pekanbaru, 28293, Indonesia \\ "E-mail: anggiasetianing@gmail.com
}

\begin{abstract}
ABSTRAK
Penelitian ini bertujuan untuk mengetahui pengaruh model pembelajaran inkuiri terbimbing melalui media adobe flash terhadap hasil belajar kimia siswa kelas XI. Penelitian ini dilatarbelakangi oleh rendahnya hasil belajar kimia siswa kelas XI MIA. Jenis penelitian yang digunakan adalah kuasi eksperimen (eksperimen semu) dengan desain pretest dan posttest. Subjek penelitian ini adalah siswa kelas XI MIA tahun ajaran 2016/2017 dengan jumlah sampel dua kelas yaitu XI MIA 2 (kontrol) berjumlah 24 siswa dan XI MIA 3 (eksperimen) berjumlah 25 siswa. Data penelitian dikumpulkan melalui observasi, tes data awal yaitu tes homogenitas dan tes data akhir yaitu pretest dan posttest, serta dokumentasi. Hasil penelitian menunjukkan adanya pengaruh penerapan model pembelajaran inkuiri terbimbing melalui media adobe flash terhadap hasil belajar kimia siswa kelas XI SMA pada materi kelarutan dan hasil kali kelarutan, dengan pengaruh sebesar 9,94\%.
\end{abstract}

Kata kunci: inkuiri terbimbing, media adobe flash, hasil belajar, kelarutan dan hasil kali kelarutan.

\begin{abstract}
This research was intended to investigate the effect of guided inquiry learning with adobe flash media toward students' chemistry learning outcomes at the eleventh grade. This research was instigated by the students' low chemistry learning achievement at the eleventh grade of science class. This research is a quasy-experimental study with pretest and posttest design. The subjects of this research were the eleventh grade students of science class (MIA) in 2016/2017 academic year. There were two classes of samples, i.e. the eleventh grade students of MIA 2 (24 students) as control class and the eleventh grade students of MIA 3 (25 students) as experiment class. Research data as collected through observation, homogeneity test as the preliminary data test, pretest and posttest as the final data test, and documentation. The results show that there was an effect of using guided inquiry learning model with adobe flash media toward student chemistry learning outcomes on the concept of solubility and solubility product and the effect was $9.94 \%$.
\end{abstract}

Keywords: guided inquiry, adobe flash media, learning achievement, solubility and solubility product constant.

DOI: https://doi.org/10.15575/jtk.v3i2.3663 


\section{PENDAHULUAN}

Kegiatan belajar mengajar tidak lepas dari peran seorang guru dalam menggunakan model pembelajaran. Oleh sebab itu, perlulah pemilihan model pembelajaran yang tepat dalam perubahan hasil belajar siswa menjadi lebih baik. Salah satu model pembelajaran yang direkomendasikan untuk digunakan dalam kurikulum 2013 ialah inkuiri. Menurut Winataputra, model inkuiri terbimbing merupakan salah satu model atau kegiatan penyajian materi pelajaran untuk memperoleh pengetahuan yang dilakukan dengan cara menyelidiki sendiri (Wijiastuti, 2011).

Hasil penelitian Yulianingsih dan Hadisaputro, menunjukkan bahwa model inkuiri terbimbing lebih baik dalam meningkatkan hasil belajar siswa (Yulianingsih \& Hadisaputro, 2013). Begitu juga dengan hasil penelitian Nuari yang menunjukkan bahwa terdapat pengaruh model pembelajaran inkuiri terbimbing terhadap hasil belajar siswa (Nuari dkk., 2015). Hal ini mengindikasikan bahwa penggunaan model pembelajaran inkuiri terbimbing dapat mempengaruhi hasil belajar siswa.

Dalam proses pembelajaran banyak komponen yang mempengaruhi hasil belajar, antara lain: tujuan, materi yang dipelajari, model pembelajaran, siswa dan guru sebagai subjek belajar, media pembelajaran, dan penunjang proses pembelajaran. Menurut Santoso S. Hamidjojo, media pembelajaran adalah media yang penggunaannya diintegrasikan dengan tujuan dan isi pelajaran yang bermaksud untuk mempertinggi kegiatan belajar mengajar dalam segi mutu (Hidayat, 2013).

Hubungannya dengan media pembelajaran, bahwa SMA Muhammadiyah 1 Pekanbaru dalam melaksanakan kegiatan belajar mengajar sudah menggunakan teknologi komputer (laptop/notebook). Hal ini didukung dengan fasilitas sekolah yang baik yakni tersedianya infokus di setiap kelas dan setiap guru mempunyai perangkat laptop atau notebook. Namun demikian, lengkapnya fasilitas teknologi juga berjalannya pembelajaran menggunakan komputer dengan aplikasi powerpoint sebagai medianya tidak diikuti tingginya hasil belajar siswa pada mata pelajaran kimia. Oleh karena itu, diperlukan terobosan baru dalam menggunakan media pembelajaran yang menggunakan komputer dengan aplikasi adobe flash. Dengan bantuan media adobe flash dalam proses pembelajaran diharapkan siswa terfasilitasi dalam menemukan ide-ide baru atau lebih memahami materi pembelajaran karena salah satu kelemahan inkuiri adalah fasilitas untuk mencoba ide-ide belum lengkap. Dan media adobe flash juga memfasilitasi gambar atau video secara langsung.

Mempelajari ilmu kimia dianggap sulit, karena membahas konsep-konsep yang saling berkaitan, sehingga setiap konsepnya harus dipahami dengan baik (Widiyanti \& Saptorini, 2014). Pada materi kelarutan dan hasil kali kelarutan banyak memuat soal-soal yang bersifat matematis disertai teori-teori. Kelarutan dan hasil kali kelarutan memuat sub pencapaian kompetensi yang cukup banyak, yaitu kelarutan dan Ksp, pengaruh ion senama, pengaruh $\mathrm{pH}$ terhadap kelarutan, dan reaksi pengendapan.

Berdasarkan hasil wawancara dengan salah satu guru kimia SMA Muhammadiyah 1 Pekanbaru, masalah yang ditemui dalam mata pelajaran kimia yakni pada umumnya hasil belajar siswa masih tergolong rendah. Rendahnya hasil belajar ini dipengaruhi oleh kemampuan kognitif terhadap materi kimia yang masih rendah. Jika siswa mengalami kegagalan atau kemunduran dalam hasil belajar, hal ini berarti ada kesulitan yang dihadapi selama pembelajaran, karena kesulitan tersebut berdampak kurang baik terhadap pemahaman siswa (Janah dkk., 2018).

Menyikapi masalah yang timbul dalam pembelajaran kimia, maka dibutuhkan suatu variasi model pembelajaran yang tepat. Salah satunya dengan menggunakan model inkuiri terbimbing.

Berdasarkan uraian tersebut, maka tujuan penelitian ini adalah untuk mengetahui pengaruh inkuiri terbimbing melalui media adobe flash terhadap hasil belajar kimia siswa. 


\section{METODE PENELITIAN}

Penelitian ini menerapkan penelitian dengan pendekatan kuantitatif. Adapun jenis penelitian yang digunakan adalah eksperimen semu (quasy experimental) dengan pretest and posttest design. Pada penelitian ini digunakan dua kelas, yaitu kelas XI MIA 3 sebagai kelas eksperimen yang mendapat perlakuan model pembelajaran inkuiri terbimbing melalui media adobe flash dan XI MIA 2 sebagai kelas kontrol yang mendapat perlakuan tanpa menggunakan media adobe flash. Kedua kelas terlebih dahulu diberikan pretest, kemudian diberikan posttest setelah perlakuan dilakukan. Soal yang digunakan pada pretest dan posttest sama, begitu pula dengan waktu mengerjakannya.

Tabel 1. Rancangan Penelitian Pretest dan Posttest

\begin{tabular}{|c|c|c|c|}
\hline Kelompok & Pretest & Perlakuan & Posttest \\
\hline Eksperimen & $\mathrm{O}_{1}$ & $\mathrm{X}_{1}$ & $\mathrm{O}_{2}$ \\
\hline Kontrol & $\mathrm{O}_{1}$ & $\mathrm{X}_{0}$ & $\mathrm{O}_{2}$ \\
\hline
\end{tabular}

(Sukardi, 2003)

Keterangan:

$\mathrm{O}_{1}$ : Tes sebelum diberikan pembelajaran yaitu materi larutan penyangga.

$\mathrm{O}_{2}$ : Tes setelah pembelajaran yaitu materi kelarutan dan hasil kali kelarutan.

$X_{1}$ : Pembelajaran menggunakan model pembelajaran inkuiri terbimbing melalui media adobe flash (perlakuan)

$\mathrm{X}_{0}$ : Pembelajaran tanpa media adobe flash (perlakuan)

Populasi dalam penelitian ini adalah peserta didik kelas XI MIA se-Indonesia yang setara. Pengambilan sampel dilakukan dengan teknik cluster random sampling. Teknik cluster random sampling, dengan syarat semua kelas bersifat homogen dan memiliki kesempatan yang sama untuk dipilih sebagai sampel. Sampel pada penelitian ini adalah kelas XI MIA 3 sebagai kelas eksperimen yang berjumlah 25 peserta didik dan XI MIA 2 sebagai kelas kontrol yang berjumlah 24 peserta didik.

Teknik pengumpulan data dalam penelitian ini menggunakan observasi dan tes. Pada penelitian ini digunakan observasi jenis non participant observation. Hal ini dikarenakan peneliti tidak ikut serta dalam kegiatan, hanya mengamati proses pembelajaran yang dilakukan oleh guru. Tes yang digunakan dalam pengumpulan data penelitian ini adalah tes hasil belajar dalam bentuk soal objektif tipe pilihan ganda yang berjumlah 20 soal. Tes hasil belajar digunakan untuk mengukur hasil belajar siswa pada saat pretest dan posttest.

Instrumen dalam penelitian ini adalah lembar observasi dan tes hasil belajar. Lembar observasi digunakan untuk mengamati pelaksanaan kegiatan pembelajaran. Instrumen tes digunakan untuk mengukur hasil belajar siswa dengan bentuk soal pilihan ganda.

Analisis data yang dilakukan meliputi (1) Analisis untuk melihat normalitas dan homogenitas dari instrumen penelitian, (2) Analisis terhadap pengaruh model pembelajaran inkuiri terbimbing melalui media adobe flash terhadap hasil belajar kimia siswa, (3) Analisis terhadap data hasil tes dilakukan untuk melihat peningkatan hasil belajar kimia siswa dengan cara mendeskripsikan data skor hasil pretest dan posttest masing-masing siswa. Pengujian hipotesis dilakukan untuk mengetahui apakah hipotesis yang sudah dilakukan ditolak atau diterima. Untuk menguji hipotesis dalam penelitian digunakan uji-t satu pihak karena data sudah homogen dan digunakan rumus polled.

\section{HASIL DAN PEMBAHASAN}

Hipotesis dalam penelitian ini diuji dengan selisih nilai pretest dan posttest. Kelas eksperimen memiliki nilai rata-rata sebesar 29,4 dan pada kelas kontrol memiliki nilai ratarata sebesar 30,83 . Kelas eksperimen memiliki nilai rata-rata posttest sebesar 43,6 sedangkan nilai rata-rata posttest kelas kontrol sebesar 37,08 .

Kemudian dilakukan analisis data, di mana kelas eksperimen dan kelas kontrol berada pada distribusi normal dan homogen. Untuk menguji hipotesis dalam penelitian digunakan uji-t satu pihak karena data sudah homogen dan digunakan rumus polled. Dari hasil perhitungan setelah diadakan treatment 
(perlakuan), diperoleh nilai $t_{\text {hitung }}=2,28$ dan $t_{\text {tabel }}=1,678$, hal ini menunjukkan bahwa $t_{\text {hitung }}$ $>t_{\text {tabel }}$. Dapat disimpulkan bahwa hipotesis alternatif yang berbunyi "Ada pengaruh penerapan model pembelajaran inkuiri terbimbing melalui media adobe flash terhadap hasil belajar kimia siswa" diterima. Artinya terdapat peningkatan hasil belajar siswa dengan menggunakan model pembelajaran inkuiri terbimbing melalui media adobe flash, dengan peningkatan sebesar 9,94\%.

Adanya peningkatan hasil belajar peserta didik dengan menggunakan inkuiri terbimbing dikarenakan pada proses pembelajaran dengan model pembelajaran inkuiri terbimbing melalui media adobe flash, peserta didik belajar sendiri menemukan konsepkonsep materi pembelajaran. Model ini termasuk model pemrosesan informasi menekankan pada bagaimana seseorang berpikir dan dampaknya terhadap cara-cara mengolah informasi. Model pembelajaran inkuri terbimbing cocok digunakan untuk tingkat SMA karena guru memberikan banyak arahan untuk membimbing siswa dalam menyelesaikan masalah (Nuari dkk., 2015).

Penerapan model pembelajaran inkuiri terbimbing melalui media adobe flash ini mampu mengatasi permasalahan belajar di SMA Muhammadiyah 1 Pekanbaru, terlihat dari respon peserta didik yang tekun dalam mengerjakan lembar kerja peserta didik, mampu mengerjakan soal-soal dari adobe flash dimana diberi bimbingan dalam mengerjakannya, dan ketika ada peserta didik yang kurang mengerti, dengan adanya kerja kelompok teman yang mengerti mampu mengajarkan temannya yang kurang mengerti dan itu tidak lepas dari bimbingan guru, karena materi kelarutan dan hasil kali kelarutan bersifat teori dan hitungan.

Hasil yang diperoleh menunjukkan bahwa penerapan model pembelajaran inkuiri terbimbing melalui media adobe flash ini mampu membuat pemahaman peserta didik meningkat. Tahapan-tahapan inkuiri terbimbing membuat peserta didik tidak hanya menerima penjelasan dari guru saja, tetapi ada interaksi antar peserta didik di mana peserta didik berusaha untuk menemukan sendiri cara menyelesaikan permasalahan yang ada. Sesuai dengan penelitian Yoranda bahwa tahap penyelidikan (pengumpulan data) dan pemecahan masalah (analisis data) akan meningkatkan kemampuan kognitif peserta didik yang akan membawa pengaruh terhadap tingginya hasil belajar kognitif yang diperoleh (Putri, 2013).

Hasil belajar peserta didik juga bisa dilihat dari analisis ranah kognitif. Menurut taksonomi Bloom, segala upaya yang mengukur aktifitas otak adalah termasuk dalam ranah kognitif. Pada penelitian ini ranah kognitif yang digunakan adalah C1 (pengetahuan), C2 (pemahaman), C3 (penerapan), dan C4 (analisis).

Untuk proses analisisnya yaitu dengan mengelompokkan soal berdasarkan ranah kognitifnya. Pada ranah kognitif C1 (pengetahuan) berjumlah empat soal yaitu terdapat pada nomor satu sampai empat, pada ranah kognitif $\mathrm{C} 2$ (pemahaman) berjumlah lima soal yaitu terdapat pada nomor lima sampai delapan dan 20, pada ranah kognitif C3 (penerapan), berjumlah sembilan soal yang terdapat pada nomor $9,10,11,12,15,16,17$, 18, dan 19, ranah kognitif C4 (analisis) berjumlah dua soal yang terdapat pada nomor 13 dan 14.

Kemampuan kognitif pada kelas eksperimen yang menggunakan model inkuiri terbimbing melalui media adobe flash lebih unggul daripada kelas kontrol yang menggunakan metode diskusi informasi. Hal ini disebabkan karena dengan adanya model pembelajaran inkuiri terbimbing melalui media adobe flash yang diterapkan pada kelas eksperimen dapat memudahkan peserta didik memahami materi karena adanya proses bimbingan yang dilakukan guru. Hasil penelitian ini sesuai dengan pernyataan Suyanti bahwa model inkuiri memiliki kelebihan dalam membantu peserta didik mengembangkan proses kognitif peserta didik (Savitrie, 2015). Hal ini diperkuat oleh Widinda bahwa model pembelajaran inkuiri terbimbing dapat membangun 
pengetahuan peserta didik dengan bantuan bimbingan dari guru (Arlianty, 2015).

Penguasaan materi ranah kognitif C1 (pengetahuan) pada kelas eksperimen mencapai 83\% sedangkan pada kelas kontrol sebesar $77 \%$. Pada tingkat ini peserta didik dituntut untuk mengenali atau mengetahui adanya istilah, fakta, tanpa harus memahami. Adanya perbedaan tersebut disebabkan oleh peserta didik yang mengalami kelupaan dan tidak sering diulang lagi materi yang telah diajarkan.

Sejajar dengan hasil penelitian Nidawati bahwa materi pelajaran yang telah dikuasai tidak pernah digunakan atau dihafalkan oleh peseta didik merupakan salah satu faktor penyebab terjadinya lupa. Seperti dikemukakan oleh Ebbinghaus dan Boreas bahwa kelupaan dapat terjadi ketika materi yang disimpan dalam ingatan tidak sering ditimbulkan kembali dalam alam kesadaran, sehingga menyebabkan individu mengalami kelupaan. Hal ini juga dijelaskan dalam teori atropi bahwa jejak-jejak ingatan (memory traces) yang lama tidak ditimbulkan kembali maka makin lama makin mengendap, sehingga peserta didik akan mengalami kelupaan (Chussurur, 2011). Diperkuat dengan pendapat Marintan bahwa mudah lupa yang dialami peserta didik karena peserta didik hanya mengingat atau menghapal dengan menggunakan otak kiri saja atau hapal (Nirmalasari, 2011).

Pada penguasaan materi C2 (pemahaman) terlihat bahwa kelas eksperimen lebih unggul daripada kelas kontrol. Hal ini disebabkan karena pada saat peneliti mengamati proses belajar mengajar di kelas, peserta didik lebih cenderung belajar dengan menghafal. Hasil penelitian yang dilakukan oleh Pendli, Bretz dan Novak menunjukkan bahwa pada umumnya peserta didik cenderung belajar dengan cara menghapal daripada membangun pemahaman terhadap konsep-konsep kimia (Widiyowati, 2014). Hal ini sejalan dengan hasil penelitian Rahmazani bahwa hasil suatu pembelajaran dapat terlaksana jika proses pembelajaran berlangsung baik dengan melihat pengetahuan, pemahaman yang dimiliki individu (Rahmazani dkk., 2017).
Pada penguasaan materi aspek kognitif C3 (aplikasi), persentase kelas eksperimen lebih tinggi daripada kelas kontrol. Hal ini disebabkan pada model pembelajaran inkuiri terbimbing, guru bisa menjadi teman peserta didik karena adanya proses membimbing di setiap kelompok yang menjadikan peserta didik tidak takut dan malu untuk bertanya. Terlebih lagi pada ranah kognitif aplikasi terdapat sembilan soal hitungan, sehingga menyebabkan peserta didik aktif dan memudahkan peserta didik memahami cara menyelesaikan soal-soal tersebut secara efektif.

Hal ini sesuai dengan pendapat Suardana bahwa inkuiri terbimbing yang berpusat pada peserta didik dapat menjadikan peserta didik aktif (Suardana, 2007). Diperkuat oleh pendapat Muchson bahwa bila kegiatan belajar bersifat aktif, ada peluang terjadi pemahaman (Muchson, 2008).

Pada penguasaan materi ranah kognitif C4 (analisis), persentase kelas eksperimen lebih tinggi daripada kelas kontrol. Hal ini disebabkan model pembelajaran inkuiri terbimbing yang diterapkan pada kelas eksperimen merupakan model pembelajaran aktif.

Menurut Handelsman, model pembelajaran aktif terbukti dapat meningkatkan pengetahuan peserta didik. Pengetahuan ini berupa kemampuan mengingat, memahami, mengaplikasi, menganalisis, mengevaluasi, dan mencipta (Novita dkk., 2016).

Dari penguasaan materi di atas dapat disimpulkan bahwa perbedaan hasil belajar dinilai dari ranah kognitif $(\mathrm{C} 1, \mathrm{C2}, \mathrm{C} 3$, dan $\mathrm{C} 4)$ disebabkan oleh tingkat kesukaran pada tiap jenjang kognitifnya, semakin tinggi ranah kognitifnya maka tingkat kesukarannya pun bertambah.

Indikator pembelajaran dapat dicapai dengan baik pada kelas eksperimen karena keunggulan dari inkuiri terbimbing adalah proses belajar berpusat pada peserta didik, sehingga materi dapat diingat lebih lama dan memungkinkan peserta didik untuk membentuk self-concept 
yang berakibat peserta didik dapat mengenal kekuatan dan kelemahannya. Dan adanya media adobe flash yang digunakan membuat peserta didik lebih mudah dalam memahami materi pembelajaran karena adanya animasi ataupun gambar sehingga cepat untuk dipahami. Inkuiri terbimbing juga dapat melatih peserta didik untuk berpikir sendiri, sehingga menimbulkan kekuatan dan kelemahannya.

\section{KESIMPULAN}

Berdasarkan hasil penelitian dan analisis data, dapat disimpulkan bahwa ada pengaruh penerapan model pembelajaran inkuiri terbimbing melalui media adobe flash terhadap hasil belajar siswa pada pokok bahasan kelarutan dan hasil kali kelarutan. 


\section{DAFTAR PUSTAKA}

Arlianty, W. N. (2015). Pemanfaatan Penggunaan Model Pembelajaran Inkuiri Terbimbing Berbasis Konstruktivitas pada Materi Hidrolisis Garam Semester Genap SMA Negeri 1 Kartasura Tahun Ajaran 2013/2014. Universitas Islam Indonesia, $3(2), 73$.

Chussurur, M. (2011). Pengaruh Pemberian Cerita Melalui Media Audiovisual Terhadap Recall Memory Pada Anak-anak Kelas V Sekolah Dasar Takmirul Islam Surakarta. Jurnal Psikologi, 3(5).

Hidayat, S. (2013). Teori dan Prinsip Pendidikan. Tangerang: Pustaka Mandiri.

Janah, M. C., Widodo, A. T. dan Kasmui. (2018). Pengaruh Model Problem Based Learning terhadap Hasil Belajar dan Keterampilan Proses Sains. Jurnal Inovasi Pendidikan Kimia, 12(1).

Muchson, A. (2008). Strategi Menjadikan Pembelajaran Bahasa Indonesia Tidak Terlupakan Sebagai Upaya Menggalakkan Belajar Aktif. E-Jurnal Dinas Pendidikan Kota Surabaya, 1, 5.

Nirmalasari, M. (2011). Pengembangan Model Memorization Learning Dalam Meningkatkan Pemahaman Peserta Didik pada Pelajaran Kimia SMA. Edisi Khusus, (2), 180.

Novita, S., Santosa, S. \& Rinanto, Y. (2016). Perbandingan Kemampuan Analisis Siswa Melalui Penerapan Model Cooperative Learning Dengan Guided Discovery Learning. Proceeding Biology Education Conference, 359-367. Surakarta: UNS.

Nuari, A. J., Lestari, R. \& Dahlia. (2015). Pengaruh Model Pembelajaran Inkuiri Terbimbing Terhadap Hasil Belajar Siswa Kelas X di SMA Negeri 1 Rambah Tahun Pembelajaran 2015/2016. Skripsi, Fakultas Keguruan dan Ilmu Pendidikan: Universitas Pasir Pengaraian.
Putri, Y. M. D. (2013). Pengaruh Metode Pembelajaran Inkuiri Terbimbing (Guided Inquiry) untuk Meningkatkan Hasil Belajar dan Kemampuan Berpikir Tingkat Tinggi (High Order Thinking Skill) Siswa Kelas X SMA Negeri 1 Malang pada Pokok Bahasan Hidrokarbon. Skripsi, Fakultas Keguruan dan Ilmu Pendidikan: Universitas Negeri Malang.

Rahmazani., Adlim \& Safitri, R. (2017). Penerapan Model Pembelajaran Inkuiri Terbimbing untuk Meningkatkan Hasil Belajar dan Keterampilan Proses Sains Siswa pada Materi Fluida Statis", Prosiding Seminar Nasional Pascasarjana Unsyiah, 178. Unsyiah: Banda Aceh.

Savitrie, V. A. (2015). Pengaruh Inkuiri Terbimbing Terhadap Hasil Belajar Ranah Kognitif dan Keterampilan Generik Sains. Jurnal Bioterdidik, 3(10).

Suardana, I. K. (2007). Penilaian Portopolio dalam Pembelajaran Fisika Berbasis Inquiri Terbimbing di SMP Negeri 2 Singaraja. Jurnal Penelitian dan Pengembangan Pendidikan, 1(2), 129.

Sukardi. (2003). Metodologi Penelitian Pendidikan. Jakarta: PT Bumi Aksara.

Widiyanti, \& Saptorini. (2014). Penerapan tugas berbasis modified free inquiry pada praktikum untuk meningkatkan pemahaman konsep. Chemistry in Education, 2 (1).

Widiyowati, I. I. (2014). Hubungan Pemahaman Konsep Struktur Atom dan Sistem Periodik Unsur Dengan Hasil Belajar Kimia Pada Pokok Bahasan Ikatan Kimia. Pancaran, 3(4), 100. 
Wijiastuti, S. A. (2011). Pembelajaran dengan

Metode Inkuiri Terbimbing

Menggunakan Laboratorium Riil dan

Virtual Ditinjau dari Sikap Ilmiah dan

Gaya Belajar Siswa. Tesis, Program

Pascasarjana: Universitas Sebelas Maret.

Yulianingsih, U. \& Hadisaputro, S. (2013). Keefektifan Pendekatan Student Centered Learning dengan Inkuiri Terbimbing Untuk Meningkatkan Hasil Belajar. Chemistry in Education, 2(2), 155. 